\title{
MODEL EVALUASI PENERAPAN TALENT MANAGEMENT PADA PERUSAHAAN ARMADA TRUCKING
}

\author{
* Naik Henokh Parmenas ${ }^{1}$, Primadi Candra Susanto ${ }^{2}$, Erni Pratiwi Perwitasari ${ }^{3}$ \\ ${ }^{1}$ Institut Teknologi \& Bisnis Kalbis, Jakarta, Indonesia \\ 2,3 Institut Transportasi dan Logistik Trisakti, Jakarta, Indonesia
}

*Email Korespondensi: parmenas@kalbis.ac.id

\section{ARTIKEL INFORMASI}

Diterima:

25 Juni 2021

Direvisi:

12 Juli 2021

Dipublikasi:

22 Juli 2021

\section{ABSTRAK}

Penelitian ini bertujuan untuk melihat penerapan dan evalusai talent management di sebuah perusahaan jasa penyedia trucking. Paradigma baru manajemen Sumber Daya Manusia (SDM) memandang bahwa SDM adalah aset organisasi, sehingga harus dikelola secara strategis dan proaktif. Hal tersebut dimaknai sebagai keterkaitan antara pelaksanaan manajemen SDM dengan strategi organisasi untuk meningkatkan kinerja. Talent Management menjadi salah satu cara mengelola SDM secara strategis demi memaksimalkan pengembangkan potensi. Saat ini perusahaan jasa armada trucking sedang mengembangkan konsep talent management untuk menunjang visi perusahaan melalui program pengembangan talenta yang komprehensif dan berkesinambungan. Konsep/teori dasar dari talent management dan konsep degrees of maturity akan digunakan untuk menjawab perumusan masalah. Dalam penelitian ini menemukan pemahaman Divisi SDM tentang kebijakan talent management pada perusahaan jasa armada trucking masih berada pada tingkat understanding. Oleh karena itu, perusahaan perlu melakukan beberapa hal seperti evaluasi pada sistem seleksi talenta, membuat program pendidikan dan pelatihan talenta yang menarik bagi karyawan, mengubah periode penilaian kinerja lebih berkala, dan mengedukasi tentang talent management.

Kata Kunci: Talent Management, Evaluasi Penerapan, Perusahaan Trucking

\section{PENDAHULUAN}

Sumber Daya Manusia (SDM) merupakan faktor penting dan sentral dalam organisasi. Organisasi dibentuk berdasarkan visi dan misi yang dalam pencapaiannya dikelola dan dikerjakan oleh manusia, sehingga bisa dikatakan manusia merupakan faktor strategis dalam semua kegiatan organisasi. Untuk itulah, agar dapat mengatur dan mengelola SDM, dalam rangka mencapai tujuan organisasi, dibutuhkan ilmu, metode dan pendekatan pengelolaan SDM.

Berbicara tentang manajemen SDM secara umum, telah terjadi pergeseran paradigma atau cara pandang terhadap pengelolaan SDM. Paradigma baru manajemen SDM memandang bahwa SDM adalah aset organisasi atau human capital, sehingga harus dikelola secara strategis dan proaktif (Ulrich, 1998). Peran strategis dalam mengelola SDM atau sering disebut dengan manajemen SDM strategis (strategic human resource 
management) dimaknai sebagai keterkaitan antara pelaksanaan manajemen SDM dengan strategi organisasi untuk meningkatkan kinerja. Dalam implementasinya, peran strategis dalam mengelola SDM ini diartikan bahwa pengelola SDM harus dapat mengelaborasi semua kapasitas yang dimiliki pegawai atau SDM-nya, untuk dijadikan sebagai competitive advantage bagi organisasi. Manajemen SDM yang strategis seolah sudah menjadi suatu tuntutan untuk dilakukan. Terlebih lagi perubahan yang terjadi dalam lingkungan sosial yang terkait dengan karakteristik SDM saat ini yaitu era informasi yang bersumber pada pengetahuan dan teknologi yang dapat didayagunakan. Pada era ini SDM lebih ke knowledge worker, yang artinya SDM saat ini dituntut untuk memiliki pengetahuan baru yang sesuai dengan perubahan yang sedang berlangsung.

Keberhasilan organisasi/perusahaan sangat ditentukan oleh kualitas orang- orang yang bekerja di dalamnya. Dalam menghadapi perubahan lingkungan yang begitu cepat menuntut kemampuan mereka dalam menyikapi fenomena tersebut. Peran manajemen SDM dalam organisasi tidak hanya sekedar administratif, tetapi justru lebih mengarah pada bagaimana mampu mengembangkan potensi sumber daya manusia agar menjadi kreatif dan inovatif. Salah satu cara yang dapat dilakukan oleh SDM dalam mengembangkan sumber daya manusianya adalah dengan menerapkan talent management dalam perusahaan.

Dengan visi menjadi perusahaan penyedia armada trucking terkemuka yang mampu memberikan rasa aman dan manfaat optimal kepada semua pihak yang berkepentingan (stakeholder). Perusahaan jasa armada trucking berusaha terus melangkah ke depan dengan merekrut bakat-bakat dan tenaga kerja terbaik untuk menunjang visi perusahaan tersebut. Keberhasilan perusahaan jasa armada trucking sangat dipengaruhi oleh Human Capital yang dimiliki, terutama yang memiliki talenta unggul (top talent) dan dalam rangka mempersiapkan talenta untuk mengisi jabatan perusahaan, termasuk mempersiapkan top talent untuk mengisi key strategic position dibutuhkan proses identifikasi dan program pengembangan talenta yang komprehensif dan berkesinambungan.

Dengan tujuan meningkatkan kapabilitas para pegawai dan penguasaan pegawai dalam berbagai bidang pekerjaan, perusahaan jasa armada trucking secara rutin melakukan perpindahan pegawai termasuk perpindahan pegawai antar job family. Hal ini berlaku pula untuk pegawai di Divisi SDM, dimana pegawai SDM dapat berasal dari berbagai latar belakang pendidikan dan pengalaman sehingga mayoritas pegawai SDM belum memiliki kapabilitas di bidang Human Capital. Dengan keterbatasan kapabilitas pegawai di Divisi SDM tersebut, pengelolaan Human Capital dilakukan dengan mengikuti pola dengan cara kerja induk perusahaan. Dalam rangka mempersiapkan jabatan di perusahaan, serta untuk mempertahankan talenta di dalam perusahaan, maka di tahun 2021 ini perusahaan jasa armada trucking menyusun kebijakan talent management untuk diterapkan.

Mempertimbangkan hal tersebut, kami akan melakukan sharing dan evaluasi atas kebijakan talent management yang telah ditetapkan oleh perusahaan jasa armada trucking dengan melakukan komparasi kebijakan tersebut dengan konsep/teori talent management agar dapat memberi masukan kepada manajemen perusahaan jasa armada trucking .

\section{Manfaat Manajamen Talenta}

Manajemen bakat adalah bagian integral dari bisnis modern dan merupakan fungsi manajemen yang penting dalam suatu organisasi. Manajemen Talenta akan memberikan manfaat yang besar bagi perusahaan yang menerapkannya. Berikut adalah beberapa manfaat Manajemen Talenta :

\section{Menempatkan Orang Tepat pada Pekerjaan yang Tepat}

Pemetaan keterampilan atau kompetensi pada karyawan-karyawan bertalenta memungkinkan manajemen mencatat inventaris keterampilan dan kemampuan yang ada di organisasi. Ini sangat penting baik dari perspektif organisasi maupun karyawan karena orang yang tepat yang ditempatkan di posisi yang tepat akan menghasilkan peningkatan pada produktivitas karyawan. Keselarasan yang lebih baik antara minat individu dan profil pekerjaannya juga akan meningkatkan kepuasan kerja karyawan yang bersangkutan.

\section{Mempertahankan Karyawan yang bertalenta tinggi}

Meskipun ada perubahan dalam ekonomi global, pengunduran diri pada karyawan yang bertalenta tetap menjadi perhatian utama organisasi. Mempertahankan karyawan yang bertalenta tinggi penting untuk organisasi atau perusahaan untuk tetap memimpin dan bertumbuh di pasar yang tingkat persaingan yang tinggi ini. Organisasi yang gagal mempertahankan talenta terbaiknya akan berisiko kehilangan daya saingnya. Fokusnya sekarang adalah memetakan program dan strategi retensi karyawan untuk merekrut, mengembangkan, mempertahankan, dan melibatkan orang-orang berkualitas. Pertumbuhan karyawan 
dalam karir harus juga dijaga, sementara perencanaan suksesi juga dilakukan dan karyawan-karyawan yang berada di radar perlu dijaga agar mereka tahu bahwa kinerja mereka dihargai.

\section{Perekrutan yang Lebih Baik}

Kualitas organisasi adalah kualitas tenaga kerja yang dimilikinya. Cara terbaik untuk memiliki tenaga kerja yang bakat di manajemen tingkat atas adalah memiliki tenaga kerja yang berbakat di tingkat bawah juga. Tidak heran jika kemudian program dan pelatihan manajemen talenta serta penilaian perekrutan telah menjadi aspek integral dari proses SDM saat ini.

\section{Dapat lebih baik Memahami Karyawannya}

Penilaian karyawan akan memberikan wawasan mendalam kepada manajemen tentang karyawan mereka. Melalui penilaian karyawan ini, perusahaan atau organisasi dapat memahami lebih baik kebutuhan pengembangan mereka, aspirasi karir, kekuatan dan kelemahan, kepuasan kerja, kemampuan, suka dan tidak suka sehingga dapat lebih baik menentukan apa yang dapat memotivasi mereka agar dapat bekerja lebih baik sesuai dengan kebutuhan organisasinya.

\section{Keputusan pengembangan profesional yang lebih baik}

Ketika suatu organisasi mengetahui siapa memiliki potensi yang tinggi, menjadi lebih mudah untuk berinvestasi dalam pengembangan profesional mereka. Karena pengembangan membutuhkan keputusan investasi untuk pembelajaran, pelatihan dan pengembangan individu baik untuk pertumbuhan, perencanaan suksesi, manajemen kinerja dan lainnya.

Selain itu jika karyawan positif tentang praktik manajemen talenta organisasinya, mereka lebih cenderung memiliki kepercayaan terhadap masa depan organisasi mereka. Hasilnya adalah tenaga kerjanya akan yang lebih berkomitmen dan terlibat dalam mengungguli pesaing mereka serta memastikan posisi kepemimpinan perusahaan di pasar yang persaingannya sangat ketat ini.

\section{KAJIAN PUSTAKA}

Menurut Rachmawati (2014) salah satu tantangan terbesar yang dihadapi para ahli di bidang Human Resource (HR) sejak sepuluh tahun terakhir ini adalah tidak terjawabnya pertanyaan mengeni definisi dan tujuan dari manajemen talenta. Mungkin inilah alasan mengapa para praktisi HR masih merasa kesulitan dalam realisasi pelaksanaan manajemen talenta di dalam organisasi, walaupun mereka sudah menyadari bahwa manajemen talenta sangatlah penting untuk masa depan perusahaan. Wibowo et al. (2017) menyatakan bahwa talent management adalah sebuah konsep mulai dari bagaimana merencanakan, mendapatkan, mengembangkan, dan mempertahankan bakat. Dengan kata lain, talent management bukan hanya sekedar proses tunggal atau bagaimana program pengembangan berjalan, melainkan mencakup serangkaian proses. Lebih sederhana lagi, talent management adalah tentang bagaimana menempatkan orang yang tepat di tempat yang tepat dan pada waktu yang tepat. Widianingsih \& Wulansari (2018) menyatakan serangkaian aktivitas terintegrasi dalam mengelola karyawan berkinerja tinggi di semua level organisasi dengan komponen utama adalah menarik talenta melalui manajemen kinerja, pembelajaran, dan review talenta, serta mempertahankan talenta melalui perencanaan karier, perencanaan suksesi, dan mengikat talenta. Perusahaan yang menggunakan talent management sebagai salah satu strategi pengolahan SDM dapat meningkatkan kinerja pegawai sesuai tujuan perusahaan. Angliawati \& Maulyan (2020) mengatakan tantangan perusahaan saat ini adalah untuk memenangkan perang talenta (talent war), karena kemampuan memenangkan perang talenta berpengaruh kepada kemampuan memenangkan pasar. Perang talenta merupakan situasi ketika perusahaan saling berlomba mengalahkan pesaing mereka untuk memperoleh talenta terbaik yang ada di pasar tenaga kerja. Knowledge Management sebagai setiap proses (baik kebijakan formal atau metode pribadi informal) yang memfasilitasi penangkapan, distribusi, pembuatan dan penerapan pengetahuan untuk pengambilan keputusan. Knowledge Management dapat meningkatkan keahlian dan motivasi kerja sehingga mendorong peningkatan kinerja individu dan organisasi. Kinerja karyawan akan mencapai hasil lebih maksimal apabila didukung knowledge (pengetahuan) yang dimilikinya (Darmawati, 2020).

Menurut Anggraini et al. (2016) Menghadapi persaingan dunia bisnis yang semakin kompleks dan munculnya Gen Y yang telah memasuki dunia kerja dan dianggap lebih memahami teknologi maupun perspektif negatif terhadap rendahnya tingkat keterikatan Gen Y dari generasi sebelumnya, maka perusahaan perlu memperhatikan sumber daya manusia yang ada dalam suatu organisasi agar tercipta keterikatan atau employee engagement yang berdampak pada keberlangsungan suatu organisasi. Sebuah perusahaan tidak akan 
dapat berjalan tanpa didukung oleh sumber daya manusia yang handal dan sesuai dengan visi-misi perusahaan. Perusahaan perlu memperhatikan investasi sumber daya manusia dalam organisasinya dan menciptakan employee engagement. Sugiharto et al. (2019) Menyebutkan bahwa Employee Engagement terbentuk melalui komitmen peran pemimpinnya pada penyampaian dari misi, visi dan nilai-nilai organisasi yang jelas serta wewenang pemimpin untuk memberikan kebebasan kepada karyawan dalam mengambil keputusan. Salah satu bentuk kepemimpinan yang berusaha mengerahkan karyawannya adalah kepemimpinan transformasional. Kepemimpinan transformasional memberikan perhatian pada kebutuhan individu untuk tumbuh dan berkembang dengan cara berperan sebagai mentor.

Ardillah (2020) Menyatakan tingkat employee engagement pada perusahaan merupakan hal yang penting karena employee engagement menjadi sarana penyelarasan tujuan karyawan dengan tujuan organisasi. Dengan employee engagement, perusahaan dapat mengetahui apakah karyawan memiliki rasa bangga dan rasa memiliki terhadap perusahaan, mengetahui apakah karyawan memiliki keinginan untuk memberikan usaha dan kinerja ekstra terhadap perusahaan. Employee engagement sebagai tingkat sampai sejauh mana individu mengidentifikasikan dirinya dengan pekerjaannya, secara aktif berpartisipasi di dalamnya, dan menganggap performansi yang dilakukannya penting untuk keberhargaan dirinya. Keterlibatan kerja merupakan tingkat seberapa jauh individu mampu terlibat dalam sebuah organisasi di perusahaan berpartisipasi dan berkolaborasi dengan baik yang dilakukannya penting bagi harga dirinya.

Ciakaren dan Devie (2014) Mendefinisikan job satisfication sebagai perasaan positif tentang pekerjaan sebagai evaluasi karakter - karakter pekerjaan tersebut. Ketika seorang karyawan menyenangi pekerjaan mereka maka karyawan tersebut akan secara positif terlibat dengan pekerjaanya sehingga akan muncul employee engagement. Menurut Ramadhan dan Sembiring (2017) Manfaat dari employee engagement yang menyatakan bahwa employee engagement dapat meciptakan kesuksesan bagi perusahaan melalui hal-hal yang berkaitan dengan kinerja karyawan, produktivitas, keselamatan kerja, kehadiran dan retensi, kepuasan pelanggan, loyalitas pelanggan, hingga profibilitas. Kinerja karyawan menjadi salah satu hal yang menjadi akibat dari terciptanya employee engagement yang tinggi. Dalam Chrisdiana dan Rahardjo (2017) menyatakan bahwa ketidakseimbangan antara kerja dan keluarga akan menuntut pada berkurangnya performa kerja, meningkatnya tingkat absen, tingginya turn over, moral yang buruk, meningkatnya konflik dan tingginya ketidakadilan terhadap kapasitas kerja, bahwa employee engagement didefinisikan sebagai komitmen karyawan secara emosional dan intelektual untuk berkontribusi terhadap pekerjaan. mengelompokkan karyawan dalam 3 kelompok yaitu: Engaged, Not Engaged, Actively disengaged. Faktor-Faktor yang mempengaruhi employee engagement: Work Environtment (lingkungan kerja), Leadership (kepemimpinan), Team and Co-worker (tim dan hubungan rekan kerja), Training and Career Development (pelatihan dan karir) Compensation (kompensasi), Organizational Policies, procedures, structures and systems (kebijakan organisasi, prosedur, struktur, dan sistem), Workplace well-being (kesejahteraan kerja) (Handoyo \& Setiawan, 2017).

Dalam Nunoa et al. (2010) Employee engagement muncul sebagai upaya pengembangan dari konsepkonsep sebelumnya seperti kepuasan kerja karyawan, komitmen karyawan, serta perilaku organisasi karyawan. Dengan adanya karyawan yang terlibat secara aktif di dalam perusahaan menandakan bahwa perusahaan tersebut memiliki iklim kerja yang positif. Hal ini disebabkan karena dengan adanya karyawan yang memiliki keterikatan yang baik dengan perusahaan tempat ia bekerja, maka mereka akan memiliki antusiasme yang besar untuk bekerja, bahkan terkadang jauh melampaui tugas pokok yang tertuang dalam kontrak kerja mereka. Simbolon (2012) juga mengungkapkan bahwa konsep employee engagement dapat diselaraskan dengan teori Social Exchange Theory (SET), dimana hubungan yang terjadi antara karyawan dan perusahaannya terjadi dari serangkaian interaksi yang berevolusi dengan waktu dengan adanya rasa saling menguntungkan dan saling setia selama rentang kondisi tertentu. Perilaku yang menjadi anteseden dalam employee engagement dapat dilihat dari keseluruhan komitmen, minat, keterlibatan, antusiasme individu pada situasi bekerja, yang sesuai dengan tujuan organisasi serta diprediksi mampu meningkatkan efektifitas organisasi tersebut.

\section{METODE}

Metode penelitian kuantitatif dengan cara menganalisisa dokumentasi kebijakan talent management di perusahaan jasa armada trucking dan menyebar kuisioner di internal perusahaan untuk mengumpulkan informasi mengenai pemahaman konsep talent management di fungsi-fungsi terkait. 


\section{HASIL DAN PEMBAHASAN}

Evaluasi kebijakan talent management di perusahaan jasa armada trucking dilakukan dengan menyebar kuesioner kepada Divisi SDM pada perusahaan jasa armada trucking untuk menggali pemahaman mengenai kebijakan talent management yang telah ditetapkan. Pemahaman kebijakan talent management diperlukan agar implementasi kebijakan talent management oleh semua pihak yang terkait mencapai tujuannya. Untuk mengimplementasikan kebijakan talent management yang sudah dibentuk, pemahaman diperlukan sebagai tahap awal implementasi. Dalam makalah ini, Penulis mengambil sampel Divisi SDM sebagai responden kuesioner karena Divisi SDM merupakan divisi yang akan menjalankan peran penting dalam memegang talent management.

Pertanyaan pertama yang Penulis gunakan dalam survey adalah "Apa yang Anda ketahui tentang talent management?". Dari 8 responden, sebanyak 4 yang menjawab dengan benar bahwa talent management adalah pendekatan sistematis untuk menarik, mengidentifikasi, mengembangkan, retensi, dan penyebaran individu-individu dengan potensi tinggi yang memiliki nilai tertentu bagi suatu organisasi.

Pertanyaan kedua yang Penulis ajukan ialah "Menurut Anda, mengapa talent management dibutuhkan?". Sebanyak 6 dari 8 responden memahami bahwa talent management dibutuhkan untuk mempersiapkan dan memperkuat talenta perusahaan dalam melaksanakan tugasnya mencapai visi dan misi serta target perusahaan. 6 responden menyadari bahwa terdapat hubungan antara manajemen talenta dengan kinerja perusahaan. Sedangkan, 2 responden lainnya tidak menjawab secara spesifik alasan mengapa talent management dibutuhkan.

Pertanyaan ketiga yang Penulis ajukan ialah "Menurut pandangan Anda, siapa yang akan terdampak dari adanya penerapan talent management?" dan sebanyak 8 responden telah memahami bahwa organisasi, perusahaan, dan pekerja menjadi objek yang terdampak atas penerapan talent management.

Pertanyaan selanjutnya yang Penulis ajukan adalah "Kapan seharusnya talent management diimplementasikan?" dan sebanyak 5 dari 8 responden memahami bahwa talent management diimplementasikan ketika perusahaan mempersiapkan talent untuk posisi kunci dalam mendukung strategi bisnis.

Selanjutnya, Penulis mengajukan pertanyaan "Menurut Anda, apa peran anda dalam talent management?" dan jawaban yang Penulis dapatkan adalah, sebagai berikut:

a. Membuat sistem dan mempersiapkan calon pemegang kunci dalam perusahaan;

b. Penempatan pekerja baru sesuai dengan background dan pengalaman pekerja tersebut dan disesuaikan dengan kebutuhan perusahaan;

c. Mempersiapkan policy penerapan talent management;

d. Bekerja keras dan tekun untuk tercapainya target perusahaan;

e. Peran untuk saat ini adalah sebagai individu daripada telent itu sendiri serta yang dibutuhkan oleh organisasi/ perusahaan, dalam artian saya merasa pada diri sendiri untuk menuntut kepada pengembangan kualitas diri sesuai dengan yang dibutuhkan oleh organisasi/ perusahaan;

f. Berperan sebagai talent/ individu/ pekerja penggerak perusahaan yang harus menjaga skill yang bermanfaat bagi perusahaan;

g. Memberikan support kinerja terbaik dalam suatu organisasi;

h. Melakukan pembayaran pelatihan untuk meningkatkan kinerja karyawan

Pertanyaan keenam yang Penulis ajukan adalah "Berikan contoh implementasi talent management yang

berhasil yang Anda ketahui" dan jawaban yang Penulis dapatkan adalah sebagai berikut:

a. Membuat talent pool;

b. Mempersiapkan melanjutkan jenjang Pendidikan S2 di luar negeri bagi pekerja yang berprestasi dan menyiapkan berbagai unit kerja yang strategis bagi pekerja tersebut untuk mengembangkan perusahaan;

c. Identifikasi critical position \& talent mapping (performance and capacity), segmenting talent dengan 9 matriks, kalibrasi list talent oleh talent committee, development \& retention plan baru succession planning;

d. Menggunakan kemampuan saya sesuai bidang/jobdesk saya;

e. Contoh implementasi yang berhasil salah satunya dimana organisasi/perusahaan di divisi mengadakan program evaluasi training pekerja secara Digital menggunakan QUIZIZZ atau Kahoot. Sebelumnya dilakukan secara manual melalui lembar kerja, menjadi dilakukan secara online, diapat dilakukan 
bersamaan pada satu waktu namun berbeda lokasi, mengingat unit kerja yang dikelola yaitu dari lintas daerah seluruh Indonesia. Sehingga akan lebih efisien dan akurat;

f. Contohnya perusahaan mengadakan pelatihan untuk pekerja dan pekerja tersebut dapat mengimplementasikan hasil yang diperoleh dari pelatihan yang telah dilakukan;

g. Memberikan ide inovasi percepatan dalam proses bisnis yang ada dalam suatu perusahaan, dan memberikan solusi jangka panjang dalam penerapan proses bisnis yang cepat dan tepat;

h. Program BFLP.

Pertanyaan selanjutnya yang Penulis ajukan adalah "Bagaimana konsep talent management yang diterapkan pada perusahaan Anda?" dan jawaban yang Penulis dapatkan adalah sebagai berikut:

a. Dipersiapkan mulai evaluasi dan mendidik dan disiapkan dalam telent pool;

b. Penempatan pekerja terbaik di unit kerja tertentu untuk mengembangkan dan pemerataan bisnis perusahaan;

c. Sama dengan jawaban sebelumnya;

d. Perusahaan saya menopang talent management bagi karyawannya melalui training dan workshop serta praktek langsung di lapangan;

e. Konsep talent management di perusahaan sedang proses ke arah pengembangan SDM yang menitikberatkan kepada individu menjadi insan yang dapat menghasilkan inovasi dari segala hal yang sifatnya positif untuk organisasi/perusahaan. Terkait hal itu organisasi/perusahaan membuat individu atau karyawan itu sendiri merasa nyaman di lingkungan kerja dengan membuat konsep Fun Work, sehingga individu/ karyawan merasa nyaman dalam bekerja, karena sebagian besar jumlah individu/ karyawan di lingkungan organisasi perusaan sebagaian besar adalah milenial;

f. Mengadakan pelatihan dan pengembangan untuk pekerja, assessment;

g. Memberikan arahan, pendekatan (coaching and mentoring) untuk menggali potensi yang ada di masingmasing individu;

h. Memilih karyawan terbaik.

Pertanyaan terakhir yang Penulis ajukan dalam survey ini adalah "Bagaimana strategi talent management yang ada mendukung strategi bisnis perusahaan Anda?" dan jawaban yang Penulis dapatkan adalah sebagai berikut:

a. Talent yang ada dipersiapkan dengan kebutuhan strategi bisnis perusahaan;

b. Penilaian pekerja;

c. Melakukan development dan retention plan yang disesuaikan dengan trend source terkini;

d. Dengan talent management yang sekarang bisnis perusahaan kami bisa terus mendapatkan peningkatan laba dan mendekati target perusahaan;

e. Menurut saya sangat mendukung, dimana pada masa pandemi saat ini sangat diperlukan konsep digitalisasi pada organisasi/perusahaan, saat ini perusahaan sedang mengembangkan konsep tersebut yaitu milenial dan digital, sehingga dari segi bisnis akan berpengaruh signifikan terhadap pencapaian atau tujuan daripada bisnis di perusahaan;

f. Mempertahanakan dan mengembangkan pekerja yang sudah ada dalam suatu organisasi dalam menggali minat, bakat dan potensi masing-masing individu;

g. Seleksi pekerja.

Dari seluruh jawaban, setengah responden mengetahui talent management. Namun, mayoritas responden memahami bahwa talent management diperlukan untuk memperkuat talenta perusahaan demi tercapainya visi dan misi perusahaan dan diimplementasikan pada saat perusahaan mencari talenta untuk posisi kunci dalam organisasi. Selain itu, para responden juga memahami bahwa organisasi, perusahaan, serta pekerja menjadi peran yang mendapatkan dampak dari penerapan talent management. Selanjutnya, dari seluruh responden, mayoritas telah memahami perannya dalam kebijakan talent management perusahaan jasa armada trucking dan contoh dari implementasi talent management secara umum. Namun, pemahaman responden terkait talent management dinilai masih belum cukup mengenai relasi antara strategi talent management dan strategi bisnis perusahaan.

Peneliti menyimpulkan bahwa dari seluruh jawaban yang telah diberikan para responden, kebijakan talent management pada perusahaan jasa armada trucking masih berada di tingkat understanding/pemahaman. Divisi SDM dipandang telah menyadari dan memahami kebijakan talent management, namun masih dibutuhkan penerimaan bahwa strategi kebijakan talent management dengan strategi bisnis perusahaan saling berkaitan dan talent management merupakan strategi penting dalam perusahaan. 
Dari talent management yang sudah dimiliki manajemen, perekrutan SDM sudah tidak berdasarkan arahan dari manajemen atas, karena perekrutan saat ini sudah dilakukan sesuai kebutuhan perusahaan. Perekrutan yang dilakukan juga sudah tergabung dengan strategi bisnis perusahaan. Proses orientasi yang diberikan kepada karyawan diberikan dan disesuaikan dengan posisi yang ditempatkan secara berkecukupan. Fokus "mulai bekerja" sudah bersamaan dengan strategi kohesif untuk menciptakan lingkungan dan alat untuk mencapai kinerja yang optimal. Keterlibatan manajemen dengan karyawan sudah didasarkan pada nilai atau standar perusahaan. Dari penjelasan ini, dapat disimpulkan bahwa talent management perusahaan jasa armada trucking sudah tidak lagi berada pada level awareness.

Talent dipandang tidak hanya sebagai biaya bisnis, namun juga sebagai aset perusahaan. Selain itu, mayoritas masyarakat dalam organisasi melihat kebutuhan untuk perencanaan tenaga kerja strategis (workforce planning). Strategi perekrutan difokuskan pada kebutuhan jangka panjang. Proses orientasi yang ada sudah cukup baik, melihat proses orientasi yang didesain disesuaikan dengan posisinya, namun masih perlu disempurnakan. Kesempatan pelatihan sudah ditawarkan oleh perusahaan dan terintegrasi dengan misi organisasi yang masih berkembang. Talent gaps telah diantisipasi oleh talent management yang sudah ada. Talenta terbaik diakui dan dipersiapkan tidak hanya berdasarkan hubungan pribadi, namun sudah berdasarkan penilaian kinerja karyawan tersebut.

Untuk meningkatkan perusahaan jasa armada trucking berada pada tingkatan selanjutnya yaitu Tingkatan Penerimaan/Acceptance of how talent management strategies can improve business results, maka manajemen dalam hal perekrutan yang mempunyai tujuan untuk dapat disesuaikan dengan strategi bisnis dan dapat menyusun pelatihan yang akan diberikan kepada karyawan untuk dapat dilihat sebagai investasi perusahaan, kemudian dalam menyusun kurikulum pelatihan agar dapat terintegrasi dengan strategi bisnis.

\section{KESIMPLAN DAN SARAN}

Keberhasilan perusahaan jasa armada trucking menjadi berkembang dan menghasilkan keuntungan salah satunya dipengaruhi oleh keberhasilan manajemen. Kemampuan manajer dan pimipinan untuk mengoptimalkan sumber daya yang dimiliki baik itu sumber daya manusia, modal dan juga aset yang telah dimiliki. Talent management merupakan bagian dari pengelolaan sumber daya manusia yang berhubungan langsung dengan 3 kegiatan. Ketiga kegiatan tersebut merupakan landasan dari keberhasilan mengelola sumber daya manusia sehingga memberi kontribusi positif bagi perusahaan jasa armada trucking:

1. Talent management adalah proses pengembangan dan pendidikan bagian dari sumber daya manusia yang baru saja masuk ke dalam perusahaan jasa armada trucking. Setelah seorang pegawai diputuskan oleh departemen sumber daya manusia untuk diterima bekerja, maka pengembangan karyawan agar memperkuat kemampuan dalam berkontribusi ketika bekerja. Mendapatkan karyawan dengan kemampuan dan ketrampilan yang baik akan memberi manfaat optimal bagi perusahaan jasa armada trucking, memaksimalkan kemampuan dan keterampilan karyawan menjadi sangat penting sebagai bagian dari pengelolaan sumber daya manusia.

2. Proses kedua dari talent management adalah mengembangkan kemampuan dan memelihara karyawan yang sudah ada di perusahaan jasa armada trucking ini merupakan kegiatan yang penting, karena kehilangan karyawan dengan kemampuan yang baik dan berkembang berkat program pengembangan sumber daya manusia di perusahaan tersebut akan sangat merugikan. Mempertahankan karyawan dapat dilakukan dengan meningkatkan kesejahteraan, memelihara kondisi lingkungan kerja yang ramah dan baik hingga memberikan tantangan baru dalam setiap kegiatan di perusahaan.

3. Bagian ketiga adalah menarik karyawan dengan kemampuan atau kompetensi yang baik, komitmen yang tinggi dan karakter yang baik untuk bekerja di perusahaan. Mendapatkan karyawan berkualitas merupakan sebuah tantangan dalam talent management, proses selanjutnya adalah memelihara dan mengembangkan kemampuan setiap karyawan yang sudah bekerja di perusahaan. Perusahaan dapat memanfaatkan pelaku talent managementsebagai bagian dari metode mengelola sumber daya manusia di sebuah perusahaan.

Perusahaan jasa armada trucking memiliki 5 (lima) tahapan dalam siklus talent management, yang terdiri atas attraction, identification, selection, development, dan succession. Siklus ini merupakan siklus 
yang harus dilakukan dalam menentukan posisi kunci dalam organisasi perusahaan. Untuk menerapkan implementasi dari kebijakan talent management perusahaan jasa armada trucking, pemahaman diperlukan oleh berbagai peranan yang terlibat, salah satunya adalah Divisi SDM pada perusahaan jasa armada trucking.

Dari survey yang peneliti lakukan pada Divisi SDM mengenai pemahaman dalam menerapkan kebijakan talent management dalam perusahaan jasa armada trucking, mayoritas telah memahami talent management secara umum dan tujuan dibentuknya talent management itu sendiri. Penulis melihat bahwa dari pemahaman yang dimiliki Divisi SDM, kebijakan talent management pada perusahaan jasa armada trucking masih berada pada tingkat understanding/pemahaman, sehingga masih dibutuhkan pemahaman bahwa strategi kebijakan talent management perusahaan jasa armada trucking dengan strategi bisnis perusahaan saling berkaitan dan penerimaan bahwa talent management merupakan strategi penting dalam perusahaan. Selain itu, pemahaman mengenai siklus pun diperlukan supaya Divisi SDM sendiri mengetahui perannya dalam siklus talent management. 


\section{DAFTAR PUSTAKA}

Anggraini, L., Astuti, E., \& Prasetya, A. (2016). Faktor-Faktor Yang Mempengaruhi Employee Engagement Generasi Y (Studi Pada Karyawan PT Unilever Indonesia Tbk-Surabaya). Jurnal Administrasi Bisnis SI Universitas Brawijaya, 37(2), 183-191.

Angliawati, R. Y., \& Maulyan, F. F. (2020). Peran Talent Management dalam Pembangunan SDM yang Unggul. Jurnal Sain Manajemen, 2(2), 28-40.

Ardillah, S. (2020). Pengaruh Sistem Manajemen Rekruitmen, Employee Engagement, Kompensasi Terhadap Motivasi Kerja Untuk Meningkatkan Kinerja Karyawan Pada Perusahaan Expedisi Di Kecamatan Pabean Cantikan Surabaya. Media Mahardhika, 18(3), 364. https://doi.org/10.29062/mahardika.v18i3.175

Chrisdiana, L., \& Rahardjo, M. (2017). Pengaruh Employee Engagement Dan Work Life Balance Terhadap Turn Over Intention Di Generasi Millenial. Jurnal Manajemen Bisnis Dan Kewirausahaan, 1(1), 01-07.

Ciakaren, E. H., \& Devie. (2014). Analisis Transformational Leadership Terhadap Financial Performance Melalui Employee Engagement dan Job Satisfaction Pada Perusahaan Perbankan Di Surabaya. Bussiness Accounting Review, 2(2), 228-237.

Darmawati, H. (2020). Pengaruh Knowledge Management dan Talent Management terhadap Pengembangan Karir Karyawan. Journal Riset Manajemen, 4(2), 36-41.

Handoyo, A., \& Setiawan, R. (2017). Pengaruh Employee Engagement Terhadap Kinerja Karyawan Pada PT. Tirta Rejeki Dewata. Agora, 5(1), 1-8.

Katili, Putiri Bhuana, A. W. S. H. (2017). Analisi Pengaruh Employee Competence , Job Satisfaction , dan Employee Engagement Terhadap Employee Performance. Journal Industrial Servicess, 3(1), 20.

Nunoa, S. I. I. U., Andres, S., Avasola, R., Ramos, A. S., Rivera, D., Segura, K., Thraves, E., Con, L. E. A., Las, A., Para, C., Cambio, D. O., Zakeri, F., Hirobe, T., Noghabi, K. A., Kašuba, V., Rozgaj, R., Jazbec, A., Castro, A., Martínez, A., ... Poropat, M. . (2010). Employee Engagement Sebagai Kunci Meningkatkan Kinerja Karyawan (International Journal Review). Among Makarti, 5(12), 982-992. https://www.scopus.com/inward/record.uri?eid=2-s2.0-

33645547325\%7B \&\%7DpartnerID=40\%7B \&\%7Dmd5=5c937a0c35f8be4ce16cb392381256da

Rachmawati, M. (2014). Strategi untuk Menerapkan Talent Management (Manajemen Talenta) dalam Perusahaan. International Journal of Management, Economics and Social Sciences, 7(14), 53-64. https://doi.org/10.1007/s13398-014-0173-7.2

Ramadhan, N., \& Sembiring, J. (2017). Pengaruh Employee Engagement Terhadap Kinerja Karyawan Di Human Capital Center PT. Telekomunikasi Indonesia, Tbk. Jurnal Manajemen Indonesia, 14(1), 47. https://doi.org/10.25124/jmi.v14i1.351

Simbolon, H. (2012). Employee Engagement Terhadap Turnover Intention. Human Capital Innovation, 2(1), 35.

Sugiharto, M. D., Transformasional, K., \& Organisasi, B. (2019). Organisasi Terhadap Employee Engagement Generasi Y Transformational Leadership and Organizational Culture. Jurnal Manajerial, 18(2), 63-74.

Wibowo, F. A., Buana, Y., \& Kurniawan, Y. J. (2017). Analisis Pengaruh Talent Management Terhadap Organizational Performance Dan Dampaknya Pada Employee Retention. Jurnal Administrasi Dan Kesekretarisan, 3(September), 150-160. http://jurnal.stiks-tarakanita.ac.id/

Widianingsih, N. K. N., \& Wulansari, P. (2018). Pengaruh Talent Management Terhadao Meningkatnya Kinerja Karyawan (Studi Kasus pada Wilayah Telkom Bandung). E-Proceeding of Management, 5(2), 1960-1967. 